\title{
OBSERVATIONS ON THE QUATERNARY GEOLOGY OF THE RØDEFJORD REGION, SCORESBY SUND, EAST GREENLAND
}

\author{
Svend Funder
}

\section{Introduction}

During the summer of 1970 mapping of Quaternary geology was carried out in the inner part of the Scoresby Sund fjord complex in an area extending from Rypefjord and Harefjord through Rødefjord and Fønfjord to Gåsepynt (map 3). The rock types in this part of the Scoresby Sund area are mainly crystalline rocks of Caledonian and pre-Caledonian origin forming high mountain plateaus with gently undulating surfaces $1500-2000 \mathrm{~m}$ above sea level and with independant ice caps. A postCaledonian red conglomerate occurs in areas along Rypefjord, Harefjord and Rødefjord; due to the easy erosion of this rather loose sedimentary rock it now occurs as areas of smooth lowland.

Along both sides of Fønfjord the crystalline rocks are capped by Tertiary plateau basalts which due to disection of the rocks by numerous cirque glaciers now appear with a wild and alpine topography, the peaks reaching altitudes of $1500 \mathrm{~m}$.

Among the fjords in the region only Fønfjord has been surveyed (Thorson, 1934). This fjord has depths down to $1000 \mathrm{~m}$ in its inner parts and is separated from the Scoresby Sund basin by a threshold at Danmark $\varnothing$. The fjords all terminate in calving glaciers which are outlets of the Inland Ice.

The inner part of Scoresby Sund has been little visited by scientific expeditions in the past. Scattered observations on the Quaternary geology of the area were made during the expedition led by C. Ryder in 1891-1892 (Bay, 1895). This source, together with information from aerial photographs, was used in the compilation of the Quaternary Map of Greenland at a scale of 1:2 500 000.

The summer of 1970 was the second of a three summer project during which it is hoped to establish a chronology of Quaternary events in the area. Glacial and marine deposits were mapped and the chronology is supported by radiocarbon dates on lacustrine deposits and bivalve shells from the marine deposits. The most significant field observations from this summer are shown on map 3. 


\section{The Milne Land Stages}

This name was proposed for some ancient glacier oscillations that took place when the fjords were still occupied by ice streams (Funder, 1970). In eastern Milne Land the stages were contemporaneous with marine shorelines $90-120 \mathrm{~m}$ above present sea level.

Moraine ridges and kame terraces deposited by ice streams in Gåsefjord and Fønfjord were observed near Gåsepynt. They were referred to the youngest Milne Land Stages on "shoreline evidence". A moraine ridge at Gåsefjord near Gåsepynt is seen to change from a "normal terrestrial" moraine ridge to a bank composed of sorted sand and gravel at an altitude of $93 \mathrm{~m}$ above sea level. Stream sections in this bank reveal that it is entirely composed of sorted material, and therefore probably was deposited in water. Since shorelines at the same altitude occur at this locality it is believed that the bank is a submarine moraine deposit reflecting the sea level at the time of its formation.

It appears from these observations and those from Rensund, on the north side of Fønfjord (Funder, 1970) that during the youngest of the Milne Land Stages the fjord was occupied by an ice stream with a highly lobate front extending from Rensund across Danmark Ø to Gåsepynt.

Moraines and kame terraces found at altitudes of 500 to $800 \mathrm{~m}$ in the interior of the region are possibly related to the Milne Land Stages.

Unfortunately it has not yet been possible to date these stages. An age of 10000 years has been tentatively suggested (Funder, 1970) but probably the later of the stages are somewhat younger than this.

\section{The Rodefjord Stages}

This term is proposed for some glacial stages in the region that are younger than the Milne Land Stages.

The deposits from these stages are dominated by extensive systems of kame terraces and kame deltas that can be followed over long distances along the fjords. They were observed in Rypefjord, Harefjord, Rødefjord and the inner part of Fønfjord. The positions of the glacier fronts during these stages appear to be controlled mainly by the local topography; this, and the general lack of push-moraines, is taken as an indication that it was a time of gradual melting and retreat of the glaciers.

The oldest individual stages included in this group were observed at the mouths of Rypefjord and Harefjord where the glacial deposits are cut by shorelines $60 \mathrm{~m}$ above sea level. A slightly younger stage in Harefjord has been dated to an age of $7140 \pm 130$ years B.P. (sample 134011, see list of dates at the end of this report). The beginning of the period of the Rødefjord Stages must be a little older than this.

The termination of the period can be seen in all parts of the region to have taken 
place immediately prior to the formation of a shoreline $35 \mathrm{~m}$ above sea level. In the northern part of the region this has been dated at $6650 \pm 125$ years B. P. (sample 134008 ); in the southern part organic sediment resting on glacio-fluviatile sand immediately behind the moraines of the Rødefjord Stages was dated at $6780 \pm 140$ (sample 134018). At this time the glaciers in the region were at or behind their present position.

Thus the Rødefjord Stages comprise a period of gradual retreat of the ice streams in the fjords until they reached a position near to that which they now occupy. The period began somewhat before 7000 years B.P. and ended about 6500 years ago.

\section{Post-Rødefjord Stages}

Finds have been made of shells of Mytilus edulis in the marine deposits that post-date the Rødefjord Stages. This bivalve species is now extinct in the region. However, its presence in post-glacial raised deposits in north-east Greenland has been noted by Nathorst as far north as $73^{\circ} \mathrm{N}$ and attributed by him to a post-glacial warm period (Nathorst, 1901, p. 304). The present northern limit for Mytilus edulis on the east coast of Greenland is $66^{\circ} \mathrm{N}$ (Ockelmann, 1958, p. 61). Several finds of subfossil Mytilus have been made in the region to the north of Scoresby Sund, and during the present work its existence was also established at a number of localities in the inner part of the Scoresby Sund region. Three of these deposits have been dated with ages falling within the range $6840 \pm 125$ to $6450 \pm 120$ years B.P. (samples 134008 , 134013 and 134015).

One of the subfossil Mytilus localities is especially interesting. This is a deposit of grey marine silt lying at the very side of Eielson Gletscher $1500 \mathrm{~m}$ north of its present front in Rypefjord: The deposit which is now being eroded by melt water streams from the glacier indicates that the glacier at the time of its formation must have been considerably behind its present position, and that between 6650 years ago and historical times the glacier has made no oscillations beyond its present limit.

That this may be true also for other glaciers in the region is indicated by an observation made by Hartz at Rolige Bræ in Rødefjord (in Bay, 1895, p. 175). Hartz found shell fragments of Chlamys (=Pecten) islandica on this glacier near its edge opposite Kobberpynt. Chlamys islandica has never been found living in the Scoresby Sund region, but it often occurs subfossil together with Mytilus edulis, (for the present distribution of Chlamys in Greenland waters see Ockelmann, 1958, p. 63). It therefore seems likely that Rolige Bræ recently advanced over marine deposits from the post-glacial warm period and that shear action in the glacier has brought shells from these to its surface.

It is concluded that there is evidence of a post-glacial warm period in the Scoresby Sund area during which the climate was somewhat warmer than it is now. The major glaciers in the fjords had shrunk to smaller volumes than they have at present. The 
bivalve species Mytilus edulis and Chlamys islandica immigrated into the region where they have since once more become extinct.

There is good agreement between the dates for the presence of Mytilus in Scoresby Sund and dates obtained by Washburn \& Stuiver (1962) and Lasca (1969) for shell samples containing Mytilus from the Mestersvig and Skeldal areas at Kong Oscar Fjord to the north of Scoresby Sund. This indicates that Mytilus lived in the region at least from shortly after 7000 years B.P. to somewhat before 5000 years B.P. which gives a minimum value for the duration of the warm period in the region.

\section{The shorelines}

Heights of shorelines were measured this summer with a Paulin barometer which was corrected several times a day at sea level.

The shorelines observed are boulder lines with sand and gravel often grading downwards into fossiliferous grey silt. On the map (map 3) the altitude of the highest shorelines observed locally have been noted. These are thought generally to represent the local marine limit, and the decrease in height of these values from $103 \mathrm{~m}$ at Gåsepynt to $35 \mathrm{~m}$ at the head of the fjords reflects the gradual/opening of the fjords due to deglaciation. However, to interpret these figures the amount of tilt in the shorelines should be known.

Since the dates for deposits containing Mytilus seem to be fairly consistent, the occurrence of this species probably forms a very rough marker horizon in the area. Therefore its occurrences and their field altitudes have been marked on map 3. Since the shells were all found in the substratum in which they lived a few metres should be added to the field altitudes in order to obtain the height of the contemporary sea level. This has been briefly discussed for each of the dated samples in the list of $\mathrm{C}^{14}$ dates in this report.

In the inner part of the region Mytilus occurs in connection with shorelines from 25 to $36 \mathrm{~m}$ above sea level. On eastern Danmark Ø (just outside the frame of map 3) Mytilus occurs in a slightly older deposit which has been related to a sea level $6 \mathrm{~m}$ above the present (sample 134013). The distance, measured in an east-west direction between this locality and those in the inner part of the region, is about $60 \mathrm{~km}$. This probably gives an idea of the tilt of the "Mytilus shoreline" in the area.

\section{References}

Bay, E. 1895: Geologi. II. Scoresby Sund. Meddr Gronland 19, 149-176.

Funder, S. 1970: Notes on the glacial geology of eastern Milne Land, Scoresby Sund, East Greenland. Rapp. Gronlands geol. Unders. 30, 37-44.

Geological Survey of Greenland, 1971 : Quaternary map of Greenland.

Lasca, N. P. 1969: The surficial geology of Skeldal, Mesters Vig, northeast Greenland. Meddr Grønland 176, 3, 59 pp.

Nathorst, A. G. 1901 : Bidrag til Nordöstra Grönlands geologi. Geol. Fören. Stockh. Förh. 23, $275-306$.

Ockelmann, W. K. 1958: Zoology of East Greenland, marine lamellibranchiata. Meddr Grønland 122, 257. pp. 
Thorson, G. 1934: Contributions to the animal ecology of the Scoresby Sound fjord complex (East Greenland). Meddr Gronland 100, 3, 69 pp.

Washburn, A. L. \& Stuiver, M. 1962: Radiocarbon-dated postglacial delevelling in northeast Greenland and its implications. Arctic 15, 66-73.

\title{
THE GEOCHRONOLOGY OF THE SCORESBY SUND AREA
}

\author{
Progress report I: $\mathrm{Rb} / \mathrm{Sr}$ mineral ages
}

\section{B. T. Hansen and R. H. Steiger}

\section{Introduction}

A general age determination programme has been proposed for the crystalline rocks of the Scoresby Sund region. The various field geologists are contributing to this by delivering material of significant rock types from their individual areas, and subsequently the actual age-determinations are carried out at the "Institut für Kristallographie und Petrographie" of the "Eidg. Technische Hochschule" in Zürich.

The first age determinations obtained from this programme are given in table 2 below.

Table 2. Preliminary $\mathrm{Rb} / \mathrm{Sr}$ mineral ages

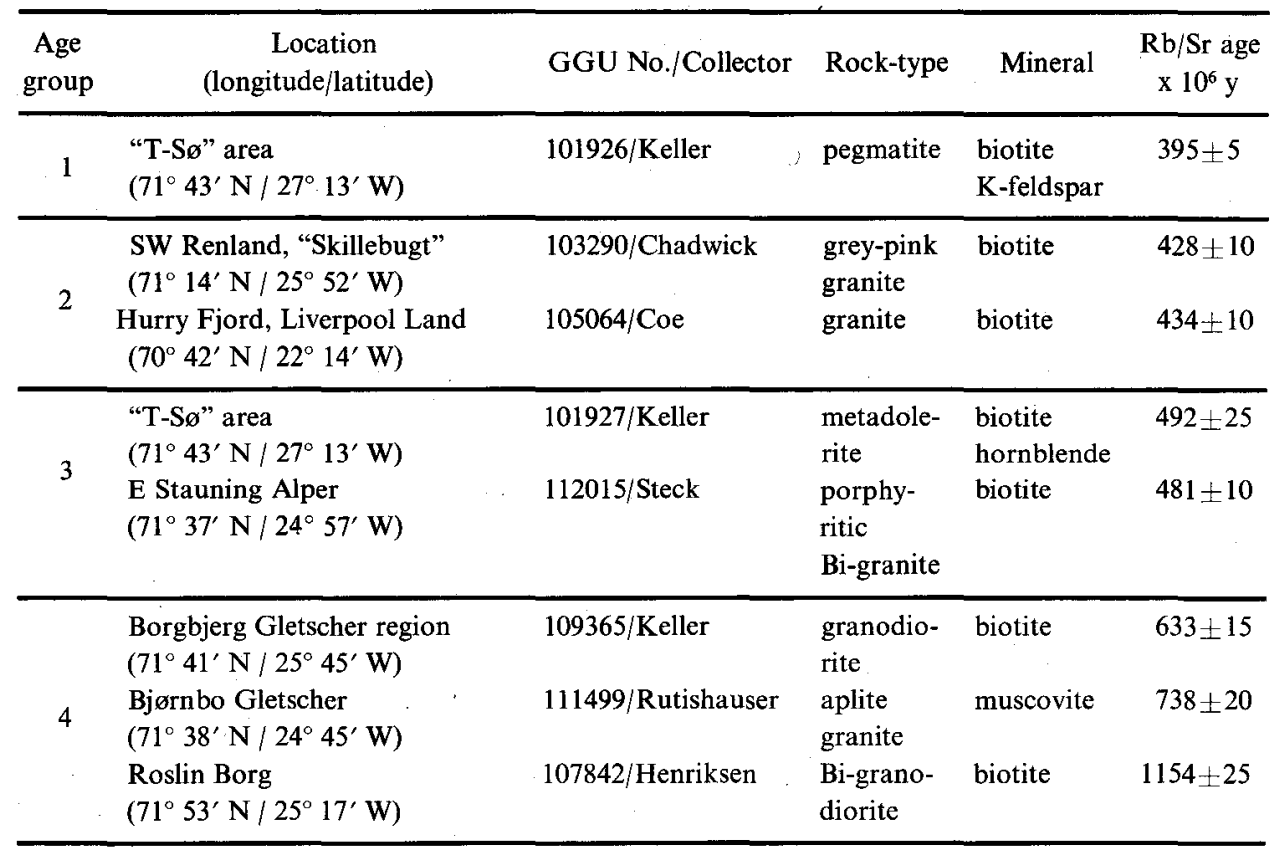

